\section{artelogie}

\section{Artelogie}

Recherche sur les arts, le patrimoine et la littérature de l'Amérique latine

\section{$11 \mid 2017$}

Délocalités, translocalités et activisme dans l'art électronique et biomédiale latino-américain

\title{
Video 2- Identidad y referencias culturales.
}

Pat Badani entrevista a Rafael Lozano Hemmer (español)

Pat Badani y Rafael Lozano Hemmer

\section{(2) OpenEdition \\ Journals}

Edición electrónica

URL: http://journals.openedition.org/artelogie/1651

DOI: $10.4000 /$ artelogie. 1651

ISSN: 2115-6395

\section{Editor}

Association ESCAL

Referencia electrónica

Pat Badani y Rafael Lozano Hemmer, "Video 2- Identidad y referencias culturales. », Artelogie [En línea], 11 | 2017, Publicado el, consultado el 15 septiembre 2020. URL : http://

journals.openedition.org/artelogie/1651

Este documento fue generado automáticamente el 15 septiembre 2020.

Association ESCAL 


\section{Video 2- Identidad y referencias culturales.}

Pat Badani entrevista a Rafael Lozano Hemmer (español)

Pat Badani y Rafael Lozano Hemmer

Este medio no se puede ver aquí. Por favor refiérase a la edición en línea http:// journals.openedition.org/artelogie/1651 